\title{
The Importance of Intellectual Capital Management in the Knowledge-based Economy
}

\author{
Noradiva Hamzah \\ Universiti Kebangsaan Malaysia \\ E-Mail: adibiez@yahoo.com.sg \\ Mohd Nazari Ismail \\ University of Malaya \\ E-Mail: mdnazari@um.edu.my
}

\begin{abstract}
An organisation's intellectual capital is said to be a source of competitive advantage and there is evidence that business success can be partly explained by its intellectual capital. Previous literature argues that the difference between the organisation's market value on the stock exchange and its book value is depends on its intellectual capital. This is a conceptual paper and it discusses on the importance of intellectual capital management to an organisation strategic management process. This study uses case study method in order to examine whether there is a linkage between an organisation's business strategy and its intellectual capital management. This study argues that intellectual capital management should be injected in an organization's strategic management process at the implementation parts. At the end of this paper, this study proposes typology that explains the linkage between business strategy and intellectual capital management.
\end{abstract}

Keywords: Intellectual Capital, Business Strategy, Intellectual Capital Management, Competitive Advantage, Knowledge-Based Economy

\section{INTROUDUCTION}

Knowledge has become the pre-eminent economic resource and is replacing financial and physical capitals as the most important capital in the new economy (O'Donnell et al., 2003; Demediuk, 2002; April, 2002). The exponential growth of information in the new economy focuses attention on the importance of managing 
knowledge-based assets in organisations. Many earlier researches found that a fit between business strategy and the organisation's internal capabilities will lead towards superior performance (Finney, Campbell and Powell, 2004; Pitts and Lei, 2003). Organisation's internal capabilities encompass of its corporate wide knowledge, skills and activities. In the new economy organisation's knowledge-based assets such as knowledge embedded in individuals and organisation form the majority of an organisation's internal capabilities. Therefore, organisation performance and success depends on how well organisation manages its knowledge-based assets.

According to Stewart (2002), the new economy stands on three pillars; first, knowledge has become what we buy, sell and do. Second, knowledge-based assets have become more important to organisation. Third, in order to prosper new management techniques, new technologies and new strategies are needed to explain the knowledgebased assets. The knowledge embedded in individuals and organisations has been termed as 'intellectual capital' (Demediuk, 2002; Sullivan, 1999; Stewart, 1997). Even though there is no solid consensus on what intellectual capital is, there is wide agreement on its definition. According to intellectual capital theorists, intellectual capital is comprised of three main components: human capital, relational capital and organisational capital. Human capital represents employee knowledge, competency and brain power. Relational capital refers relations with customers, suppliers, distributors and others related parties. Organisational capital designates the organisational systems, culture, practices and processes.

Previous studies have proved that distinctive human resource practices help to create unique competencies and in turn drive competitiveness (Pehrson, 2001; Cappelli and Crocker-Hefter, 1996). Human resource refers to the accumulated stock of knowledge, skills and abilities that the individual posses (Kamoche, 1996), and human resource management is used to increase the value of human capital and the value of anticipated returns such as productivity gains (Russells et al., 1993; Boudreau and Berger, 1985). In most of the intellectual capital literature, researchers agree that human capital or employee know how is a part of intellectual capital (e.g. Sveiby, 1997; Edvisson and Malone, 1997). Therefore, in view of the belief that intellectual capital is the most important resource in the new economy, the same argument should be applied to the other two dimensions of intellectual capital; relational capital and organisational capital. Organisations apply distinct type of strategies to consolidate their internal capabilities. However, very little study has been conducted to specifically assess the relationship 
between the organisation's vital capabilities, which are its intellectual capital and business strategy. This study argues that organisation's intellectual capital must be managed in order to remain at forefront and to maintain a competitive edge.

\section{INTELLECTUAL CAPITAL MANAGEMENT}

Johannessen, Olsen and Olaisen (2005) argue that intellectual capital is meant to deal with the increased turbulence, knowledge requirements and changing requirements in an organisation. Ulrich (1998) identify three reasons why intellectual capital management is important:

1. the demand for knowledge worker in a growing service economy is on the rise (entities linked to human capital)

2. the first line become increasingly important in relation to customer value (entities linked to networks)

3. learning and innovation become increasingly important in the new economy (organisational capital).

The resource-based view suggests that knowledge on organisational competencies is rooted in the organisational resources and in the complimentary between skills and technologies (Mouritsen et al., 2001). But this view does not illustrate how to deploy the resources in order to exploit it values (Ambrosini and Brown, 2001; Peppard and Rylander, 2001). According to Buller and McEvoy (1991, performance differences across organisations can be attributed to the variance in the organisations' resources and capabilities. Resources that are valuable, unique and difficult to imitate can provide the basis for an organisation's competitive advantage (Amit and Shoemaker, 1993; Peteraf, 1994; Barney, 1991). Finney, Campbell and Powell (2004), argue that resource management is the foundation of sustainable competitive advantage. Interestingly, most of the empirical researches in the resource-based view have found positive direct effects of resources on performance (Hitt et al., 2001; Pennings et al., 1998; Miller and Shamsie, 1996).

The value organisations obtain from their intellectual capital is the result of well reasoned, well-planed and well-executed set of management initiatives (Harrison and Sullivan, 2002). They also argue that organisations designs initiatives in order to ensure that specific forms of value deemed important to the organisations' business strategy and routinely extracted from organisations' intellectual capital. This means that the value of 
an organisation's intellectual capital depends on the type of outcome desired and the organisation's context. According to Harrison and Sullivan (2002), an organisation's context is the organisation's internal and external realities. Organisation's internal realities are concerned with direction, resources and customers. Meanwhile the organisation's external realities are related to opportunities, threats and focus on the fundamental forces affecting the long-term viability of the industry as well as the immediate opportunities available to the organisations. Harrison and Sullivan (2002) also argue that the relationship between an organisation and its context is expressed through the organisation's vision and the strategy it selects to achieve the vision.

The different strategies that can be pursued by an organisation require the support of different sets of internal capabilities. These internal capabilities include intellectual capital and thus, distinct types of intellectual capital are needed to support the strategy pursued by the organisation. To date, few scholars have identified the specific steps needed in order to manage intellectual capital more effectively. Organisations are required to develop distinct intellectual capital management in order to exploit their intellectual capital. Only when intellectual capital management is present, the intellectual capital of the organisation can be tapped effectively to support strategy. It is therefore argued that the fit between strategy and intellectual capital are imperative in delivering superior performance.

\section{STRATEGY AND INTELLECTUAL CAPITAL MANAGEMENT}

On the basis of the famous dictum 'structure follows strategy' (Chandler, 1962), it is presumed that different intellectual capital forms will result from and be associated with strategy. Each strategy is probably presents some unique challenges that have implications of intellectual capital management. Porter's (1980) competitive strategies distinguish competing organisations on the basis of cost leadership, product differentiation and market forms. Porter (1980) also argues that human resource management can help an organisation obtain advantage by lowering costs, increasing sources of products and services differentiation or by both. Therefore, this study argues that the cost leadership and differentiation strategies each require distinct forms of intellectual capital management practices. Gopalakrisnan, Biery and Keesler (1997) argue that organisations pursuing cost leadership are expected to put more emphasis on process innovation which is geared towards creating stability, consistency and minimising variation. In contrast, organisations pursuing differentiation strategy are expected to 
develop new products that are producible, marketable and have an advantage over competitors' offering. Therefore, it is expected that such organisations will often involved in product innovation which arises from creating variation (Benner and Tushman, 2003).

So far, there is no general approach to manage intellectual capital which has been accepted. In general, knowledge management has been defined as a practice that finds valuable information and transforms it into necessary knowledge which is critical to decision making and action. Knowledge management also includes the strategies and process to identify, capture, share and leverage the knowledge required to survive and to compete successfully (Hall and Adriani, 2002; Pena, 2002; Lim, 1999; Lepak and Snell, 1999). Therefore, organisations pursue different knowledge management strategies to manage the knowledge that they have. The choice depends on their priorities and capabilities. For example, cost leadership strategy requires attention to detail operations and keep cost slow. Thus, it is expected that its knowledge management will facilitate and mange knowledge related activities towards operational excellence. According to Wiig (1999b), if an organisation tries to pursue operational excellence strategy, it might produce cheaper products by increasing the benchmarking and sharing the practices between different groups inside and outside the organisation. Higher products consistency could be achieved by increasing the knowledge about the effects of product variations on customer requirements, sales and organisation's profitability. On the other hand, differentiation strategy would put more emphasis on the ability to meet customers' needs. Therefore, its knowledge management would facilitate and manage knowledge related activities towards product innovation. According to Wiig (1999a), the major benefit that organisations might gain from knowledge management when they pursue differentiation strategy is to produce further innovative and advanced products. This can be achieved by fostering personal innovation and increasing knowledge sharing among cross functional areas. Wiig (1999a) also argues that higher quality products are dispensable to customers and greater market acceptance can be achieved by superior knowledge transferring from external sources and new internal capabilities.

In concurrence with adopted strategy, organisations must undertake specific programmes and activities, provides supporting infrastructure, capabilities and sometimes create incentives to motivate employees and departments or business units. The transformation from intellectual capital to collective will lead to the formation of a common understanding and will engage attribution and sharing of real expectations. 
Volpel, (2002); Roos and Victor, (1999), have determined that there are three critical elements in strategic intellectual capital creation; strategic imagination and construction of intellectual capital, sharing of meaning emerging from intellectual capital, and transforming of identity through the assimilation of the intellectual capital. In order to facilitate and foster employee effectiveness and behaviour, organisations should support the employees' ability to think critically and creatively, place their employees in situations where they could use their capabilities, provide safe environment for employees to do their work, permit them to innovate, improvise and 'stretch' organisation policies and practices, motivate the employees to act intelligently in doing the right things (Wiig, 1999b). Employees should be allowed to act responsibly.

\section{RESEARCH PROBLEM}

The discussion above suggests that different types of strategies pursued by organisations will lead to distinct types of intellectual capital management. The purpose of this study is to explain and provides evidence on empirical and theoretical link between business strategy and intellectual capital management.

\section{RESEARCH FRAMEWORK}

According to Du Plessis (2005); Choi and Lee (2002); and Ndlela and du Toit (2001), knowledge will not engender value if it is not made accessible and utilised. Knowledge residing within individuals will not become a part of organisational knowledge until it is transferred throughout the organisation and stored in the organisational memory (Gopalakrishnan, Bierley and Kessler, 1997). To exploit and utilise the knowledge embedded in the intellectual capital, organisations need to manage this knowledge. Choi and Lee (2002); Ndlela and du Toit (2001); and Lee and Yang (2000) argue that knowledge management is needed to harness the organisations' intellectual capital. According to Mouritsen et al., (2002), it is through knowledge management that an organisation's organisation-wide knowledge resources and capabilities are combined to enable it to be fruitful and productive.

Different approaches to competition require different resources; and these different resources need to be managed differently to ensure that they create the desired value. Hence, the importance of intellectual capital as a resource must be managed effectively. However, very little has been written on how the different competitive approaches would require varying approaches in knowledge management. These variances indicate that 
organisations need to focus on developing specific forms of intellectual capital management practice that is reflective of the requirements of their competitive strategy. The proper alignment between business strategy and intellectual capital management is important to enable the effective execution of strategy. In order to simplify the abovementioned relationships, this study proposed a framework to show the possible relationship between business strategies and intellectual capital management. Figure 1 depicts the propose research framework.

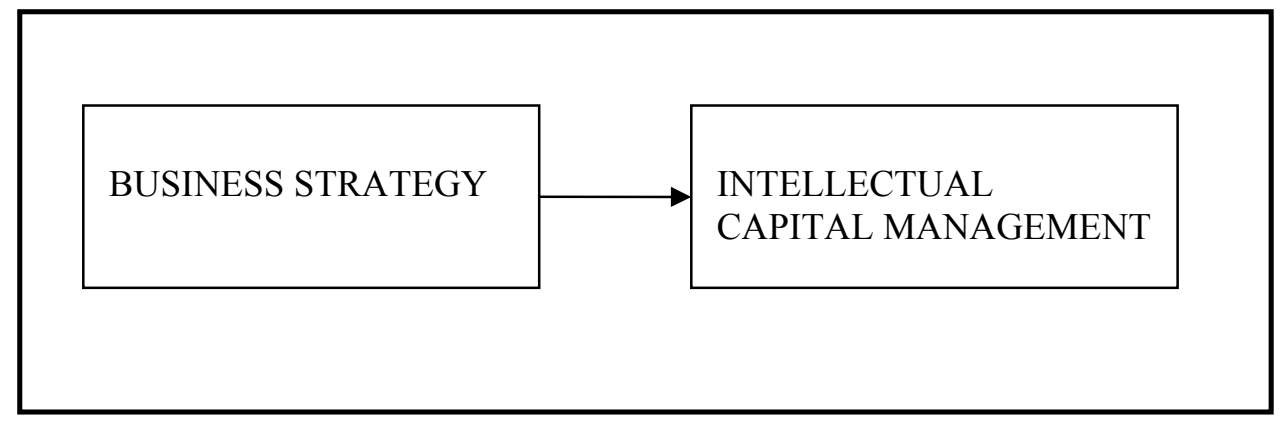

Figure 1 Intellectual Capital Management Associated with Business Strategies

The business strategy is linked to the intellectual capital management. It is presumed that different forms of intellectual capital management will result and be associated with business strategy.

\section{METHODOLOGY}

This study employs the case study method on a total of eleven organisations of four various industries (Company A, B, C,D and E are hotel operators, Company F and G are airline operators, Company $\mathrm{H}$ and $\mathrm{I}$ are from an automotive industry and Company $\mathrm{J}$ and $\mathrm{K}$ are food manufacturers). However, only organisations found to pursue differentiation or cost leadership strategy were included in this study to allow for comparison to be made between the two strategies. In order to identify whether the company is pursuing differentiation or cost leadership strategy, this study used the characteristics and definition given by Pitts and Lei (2003; Schuler (1989); Miller (1986) and Dess and Davis 1984) on Porter's generic strategies as references. For the hotels operators, list provided by the Ministry of Tourism and Heritage was referred. Only 5-star rating hotels (Company A, B and $\mathrm{C}$ were chosen for differentiation strategy. Meanwhile for cost leadership strategy the hotels were chosen from the budget hotels category (Company D 
and E).For automotive companies, Company $\mathrm{H}$ were chosen for applying differentiation strategy because it produces very special, high quality, exclusive and luxurious hand crafted sport cars. Company I was chosen for using cost leadership strategy because it produces standardized models and it cars prices are among the cheapest within the similar engine capacity. For food manufactures Company $\mathrm{J}$ was chosen because it produced high quality breads and buns Furthermore the quality of its products is recognise by Malaysia Super Brand Council. Meanwhile Company K was determined for using cost leadership strategy because it produces a similar type of bread since it first day of operation (in 1970), and the price of it breads is the cheapest in the market. Data was collected through in-depth discussions with the key personnel responsible for human resources practices and have complete knowledge about the companies' operations, observation, 'company tours' and documents were utilised to collaborate evidence information provide by the interviewees. The cross-case analysis was used to analyze and interpret the data collected. The analysis involves comparing and interpreting the evidence across the eight companies. This was done by using mixed-approach, which combining case-oriented and variable-oriented approaches to compare and interpret the evidence. Then, typology, context analysis and matrix techniques were used to develop patterns found in the evidence.

\section{FINDINGS}

\section{Organisation background}

This research includes eleven companies which are operating in various industries. They are five hotels, two airlines, two bakeries and two automotive companies. Table 1 summarizes the business activities of the companies.

\section{Business strategy pursued by companies studied}

Based on the evidence obtained from the company's documentation, interviews and direct observations, the companies are grouped according to the strategies that they are currently pursuing. Table 2 presents the summary of the companies' business strategies.

In order to identify the companies' business strategy, key characteristics acknowledged by Pitts and Lei (2003), Schuler (1989), Miller (1986) and Dess and Davis (1984) are referred to. The companies are identified by either differentiation strategy or cost leadership strategy. The findings are summarized in Table 3. 
Table 1 Business Activities

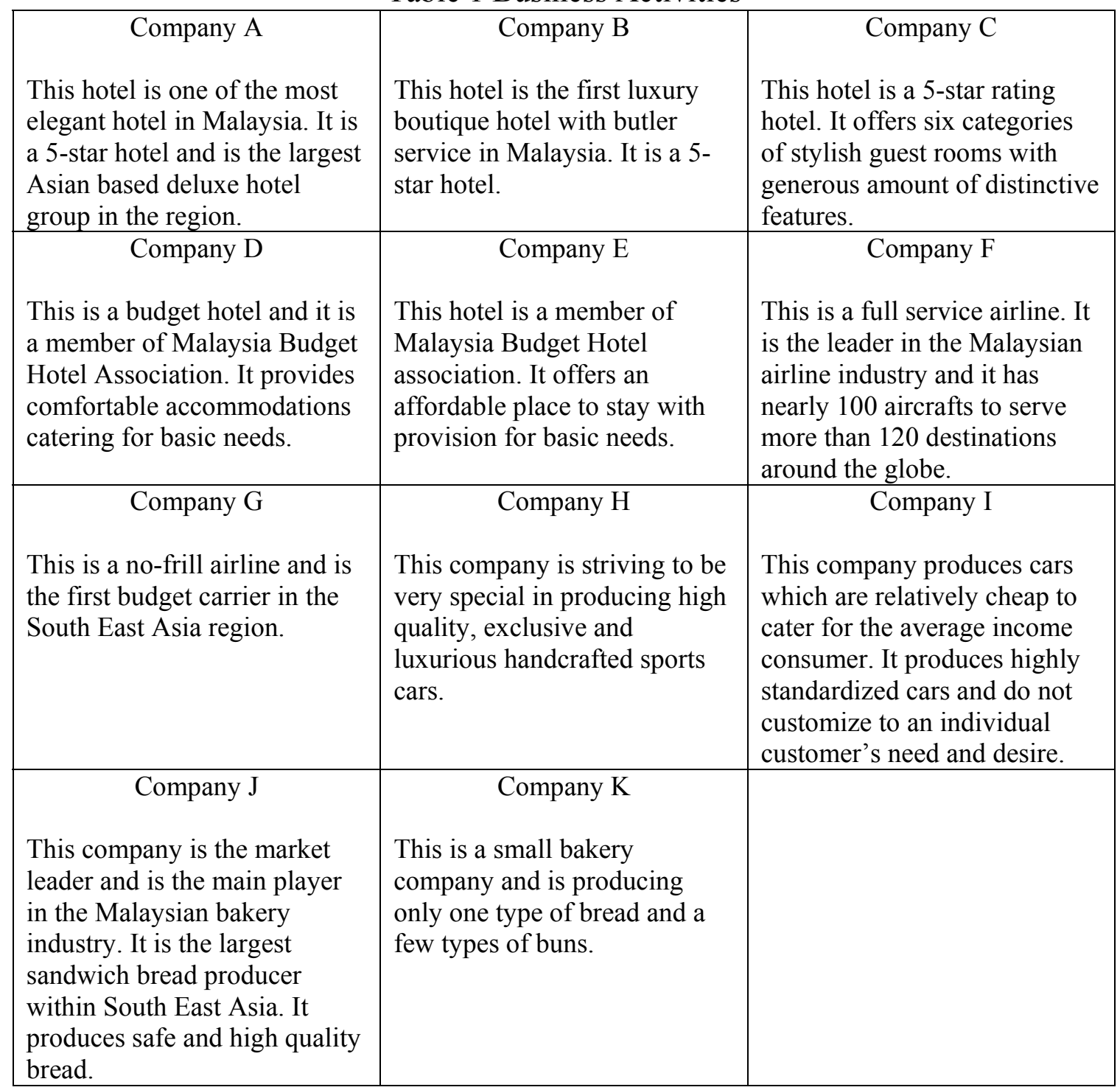


Table 2 Companies' Business Strategy

\begin{tabular}{|c|c|c|}
\hline $\begin{array}{l}\text { Company A } \\
\text { This company is very } \\
\text { committed to highly } \\
\text { personalized customer service. } \\
\text { It always made the customers } \\
\text { feel special and important. It } \\
\text { offers special luxury } \\
\text { accommodations and provides } \\
\text { very high quality and } \\
\text { distinctive services. It is a 5- } \\
\text { star rating hotel. }\end{array}$ & \begin{tabular}{l}
\multicolumn{1}{c}{ Company B } \\
This is a 5-star rating hotel \\
and is a luxury boutique hotel. \\
It emphasizes the quality of its \\
services and provides the \\
finest personal services and \\
features to its customers.
\end{tabular} & $\begin{array}{l}\quad \text { Company C } \\
\text { It emphasizes highly } \\
\text { personalized customer service } \\
\text { by highlighting its special and } \\
\text { unique ways of personalizing } \\
\text { customers. }\end{array}$ \\
\hline $\begin{array}{l}\text { Company D } \\
\text { This hotel is a member of the } \\
\text { Malaysia Budget Hotel } \\
\text { Association. In order to keep } \\
\text { rates low, it concentrates } \\
\text { totally on the main activity - } \\
\text { providing accommodation and } \\
\text { for basic needs. Employees do } \\
\text { more than one task. }\end{array}$ & $\begin{array}{l}\quad \text { Company E } \\
\text { This hotel is a member of } \\
\text { Malaysia Budget Hotel } \\
\text { Association. It provides } \\
\text { standardized amenities in } \\
\text { every room and employees are } \\
\text { expected to do more than one } \\
\text { task. }\end{array}$ & $\begin{array}{l}\quad \text { Company F } \\
\text { This company emphasizes } \\
\text { providing high quality services } \\
\text { and enhancing its services } \\
\text { continuously. It is a full- } \\
\text { service carrier and highlights } \\
\text { its slogan of 'Going Beyond } \\
\text { Expectations'. This slogan is } \\
\text { expressed through its personal } \\
\text { touch and warmth. }\end{array}$ \\
\hline $\begin{array}{l}\text { Company G } \\
\text { This is a no-frill carrier and it } \\
\text { emphasizes providing an } \\
\text { affordable air fare to everyone. } \\
\text { With its 'low fares, no frills } \\
\text { concept', this company } \\
\text { focuses on providing lower } \\
\text { fare where passengers pay just } \\
\text { for the air fare. }\end{array}$ & \begin{tabular}{l}
\multicolumn{1}{c}{ Company H } \\
This company produces very \\
special, high quality exclusive \\
and luxurious handcrafted \\
sports cars. Each individual \\
car is built its unique and \\
exclusive characteristics \\
configuration.
\end{tabular} & $\begin{array}{l}\text { Company I } \\
\text { This company produces } \\
\text { standardized models of cars } \\
\text { and the price of the cars are } \\
\text { relatively cheaper compared to } \\
\text { other cars within similar } \\
\text { engine capacity. In order to } \\
\text { keep prices low, a new model } \\
\text { is undertaken only if the } \\
\text { technology of the current } \\
\text { model is outmoded. }\end{array}$ \\
\hline $\begin{array}{l}\text { Company J } \\
\text { This company produces high } \\
\text { quality bread and continuously } \\
\text { enhances the nourishment } \\
\text { content of its products. It is } \\
\text { reputedly as one of the } \\
\text { Malaysia's super brand } \\
\text { products. It always conducts } \\
\text { market surveys in order to get } \\
\text { information about customers' } \\
\text { preferences and needs. }\end{array}$ & $\begin{array}{l}\text { Company K } \\
\text { This company produces only } \\
\text { one type of sandwich bread } \\
\text { (the similar kind from its first } \\
\text { day of operation), and a few } \\
\text { types of buns. It does not } \\
\text { customize its products to } \\
\text { customers' needs and } \\
\text { preferences. Emphasizes } \\
\text { producing lower prices bread } \\
\text { and carefully control the } \\
\text { production process to ensure } \\
\text { very minimal error, wastage } \\
\text { and damage. }\end{array}$ & \\
\hline
\end{tabular}


Table 3 Companies' Business Strategy Identified

\begin{tabular}{|c|c|c|c|c|c|c|c|c|c|c|c|}
\hline Characteristics used & $\begin{array}{c}\text { Co. } \\
\text { A }\end{array}$ & $\begin{array}{c}\text { Co. } \\
\text { B }\end{array}$ & $\begin{array}{c}\text { Co. } \\
\text { C }\end{array}$ & $\begin{array}{c}\text { Co. } \\
\text { D }\end{array}$ & $\begin{array}{c}\text { Co. } \\
\text { E }\end{array}$ & $\begin{array}{c}\text { Co. } \\
\text { F }\end{array}$ & $\begin{array}{c}\text { Co. } \\
\text { G }\end{array}$ & $\begin{array}{c}\text { Co. } \\
\mathrm{H}\end{array}$ & $\begin{array}{c}\text { Co. } \\
\text { I }\end{array}$ & $\begin{array}{c}\text { Co. } \\
\text { J }\end{array}$ & $\begin{array}{c}\text { Co. } \\
\text { K }\end{array}$ \\
\hline $\begin{array}{ll}\text { Differentiation Strategy: } \\
\text { - } & \text { Produce high } \\
\text { quality } & \\
\text { products/services } \\
\text { - } & \text { Customers are } \\
\text { special and } \\
\text { important } \\
\text { - } & \text { Services/products } \\
\text { are different, } \\
\text { unique, exclusive } \\
\text { or luxurious } \\
\text { Highly } \\
\text { personalized } \\
\text { services } \\
\text { High reliability } \\
\text { of products or } \\
\text { services } \\
\text { Continuously } \\
\text { enhance their } \\
\text { products/services } \\
\text { quality }\end{array}$ & $\begin{array}{l}\sqrt{ } \\
\sqrt{ } \\
\sqrt{ }\end{array}$ & $\sqrt{ }$ & $\sqrt{ }$ & & & 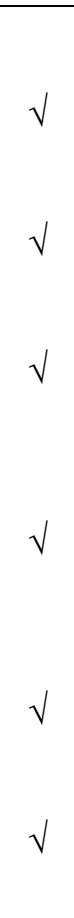 & & $\sqrt{ }$ & & $\begin{array}{l}\sqrt{ } \\
\sqrt{ } \\
\sqrt{ } \\
\sqrt{ } \\
\sqrt{ } \\
\sqrt{ }\end{array}$ & \\
\hline $\begin{array}{ll}\text { Cost Leadership Strategy: } \\
\text { - } & \text { Produce } \\
& \text { standardized } \\
\text { products } & \text { /services } \\
\text { - } & \text { Relatively } \\
& \text { cheaper } \\
\text { - } & \text { Concentrates on } \\
\text { main activity } \\
\text { - } \\
\text { Do not produce } \\
\text { products/services } \\
\text { that are } \\
\text { customized to } \\
\text { customer needs }\end{array}$ & & & & $\sqrt{ }$ & $\begin{array}{l}\sqrt{ } \\
\sqrt{ } \\
\sqrt{ } \\
\sqrt{ }\end{array}$ & & $\begin{array}{l}\sqrt{ } \\
\sqrt{ } \\
\sqrt{ }\end{array}$ & & $\begin{array}{l}\sqrt{ } \\
\sqrt{ }\end{array}$ & & $\sqrt{ }$ \\
\hline
\end{tabular}

From table 3, six of the companies (Company A, Company B, Company C, Company F, Company $\mathrm{H}$ and Company J) have been identified as pursuing differentiation strategy. These companies put emphasis on providing high quality products and services, highlighting the uniqueness of their products and services, on 
continuously enhancing the quality of their products and services and on always ensuring their products and services are different from their competitors. Company D, Company E, Company G, Company I and Company $\mathrm{K}$ on the other hand have been identified as pursuing cost leadership strategy. These companies produce highly standardized products and services, their prices are amongst the lowest in the market, their products and services are not customized to customer needs and they fully focus on their main activities.

\section{Intellectual capital management practices}

This section summarises the overall knowledge management practice developed by each company. Table 4 and Table 5 show the main focus of the knowledge management practiced by the companies in accordance with the strategy they are pursuing.

Table 4 summarises the knowledge management practices of the differentiation strategy companies. For knowledge acquisition activity, these companies focus on extracting knowledge from external resources. They send their employees to attend conferences or workshops and are actively involved with the activities and programmes of international bodies which are related to their businesses. These companies also gather new knowledge and ideas from industry and business publications. They also subscribe to trade magazines.

The knowledge that the companies have obtained from the market and customers also assists and inspires them in introducing newness and enhancing the quality of their proAs an example, like Company $\mathrm{J}$, feedback from the customers is used to increase the nourishment content of its products.

Information and new knowledge are also gathered from the feedback received from customers and are heavily used to enhance product quality and services provided. Some companies like Company A and Company B also send their employees to observe and experience products and services provided by their competitors. The evidence obtained also show that in order to trace and keep and records on customers, employees, suppliers and the market, companies that are pursuing differentiation strategy develop their own databases. For example, Company B has a system called Global Talent Inventory to record all data about its employees and customers. This data can be accessed by every employee. 


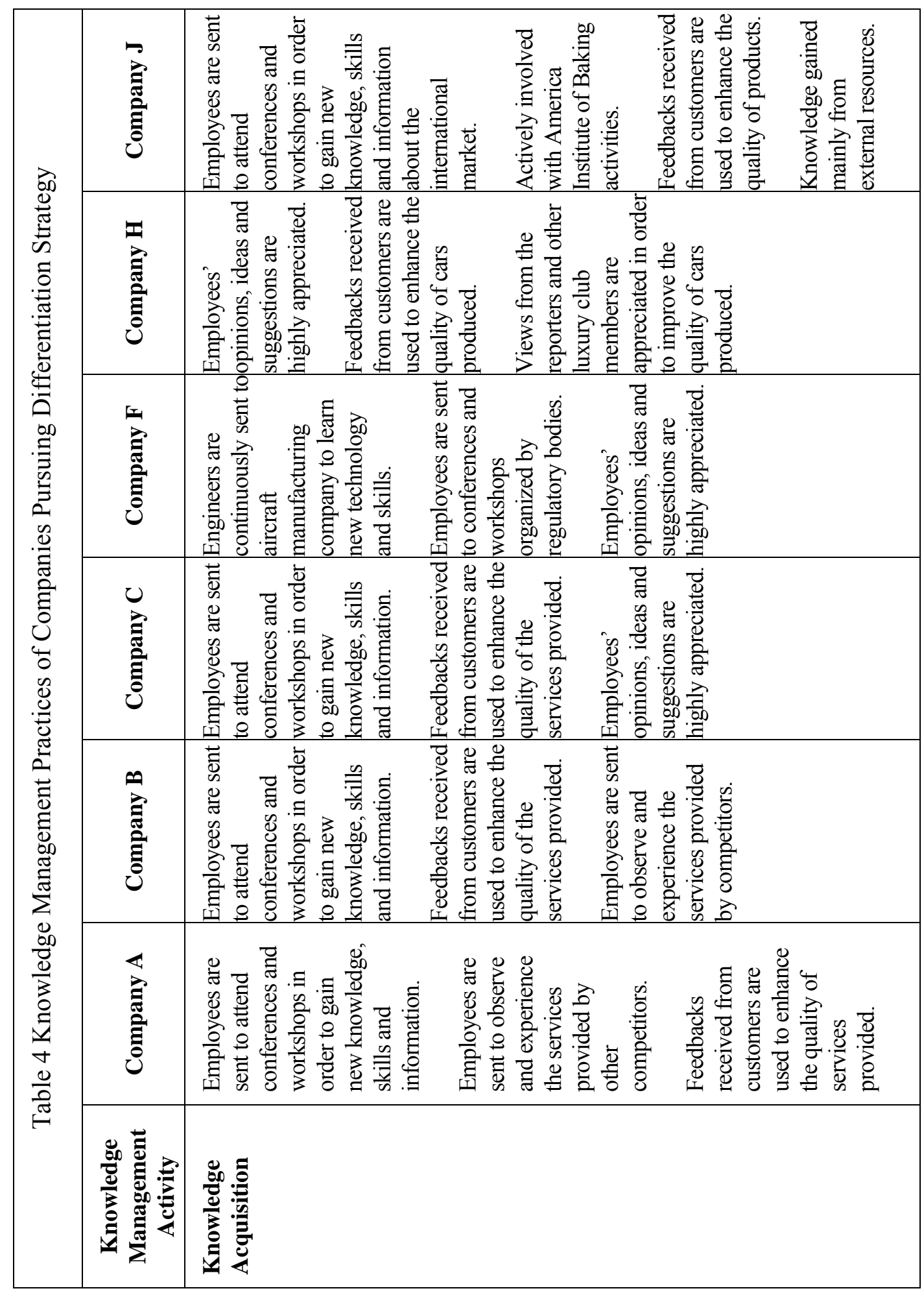




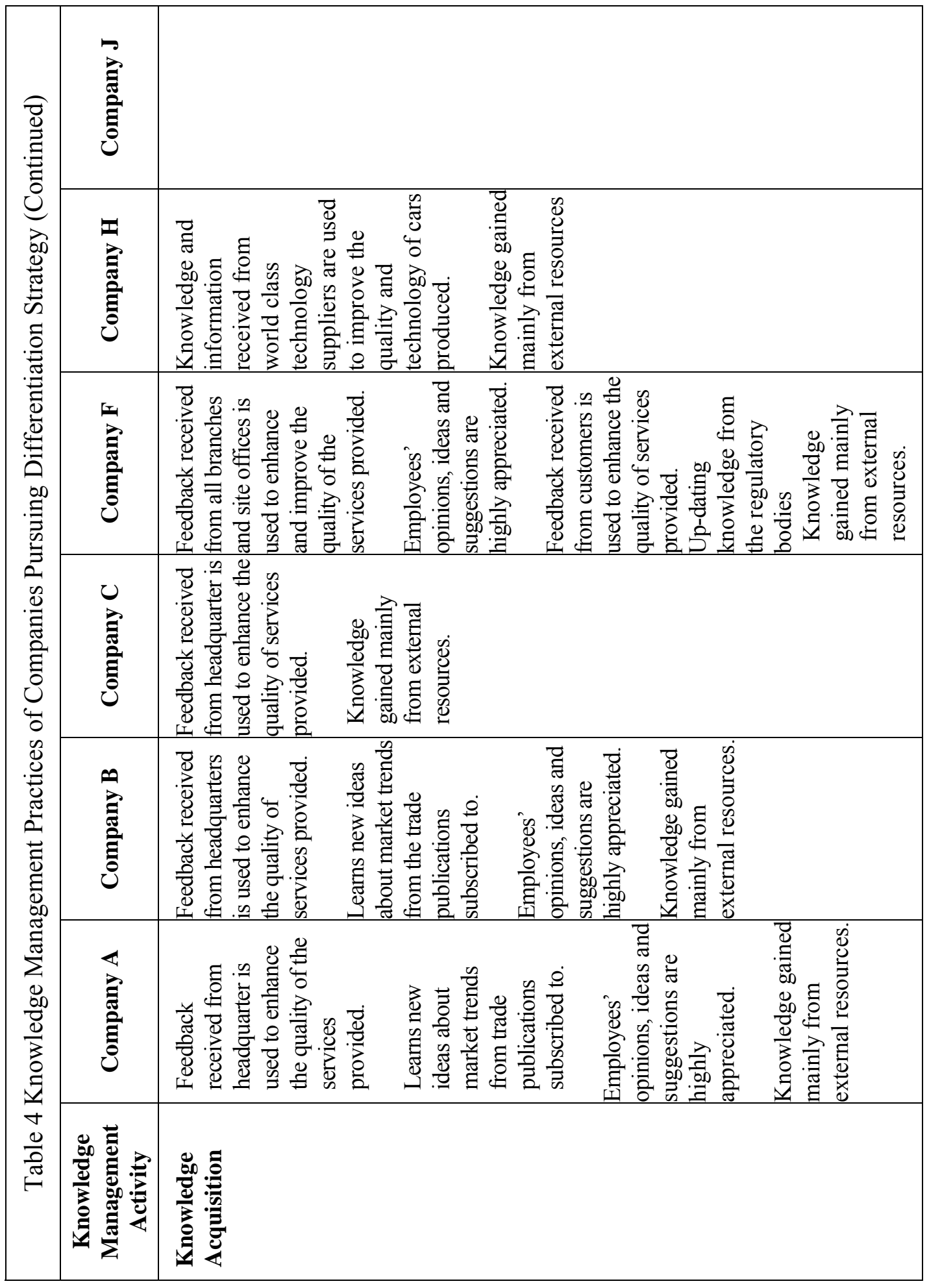




\begin{tabular}{|c|c|c|c|}
\hline \multirow{7}{*}{ 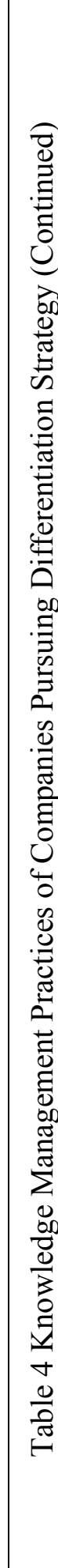 } & 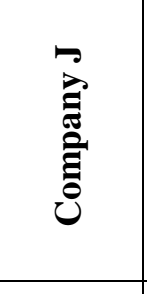 & 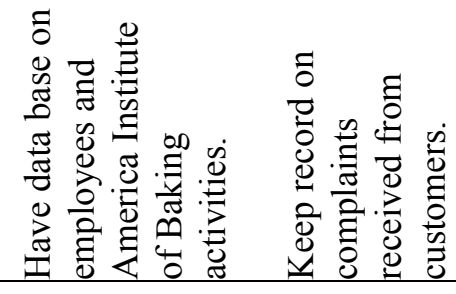 & 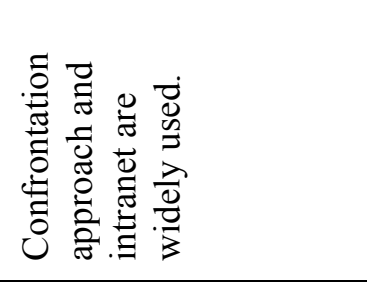 \\
\hline & 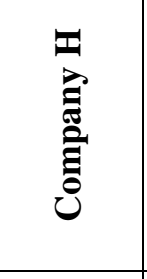 & 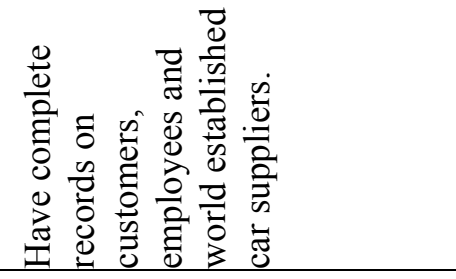 & 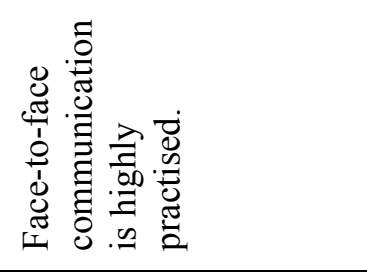 \\
\hline & نे & 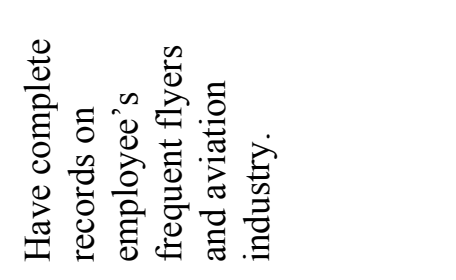 & 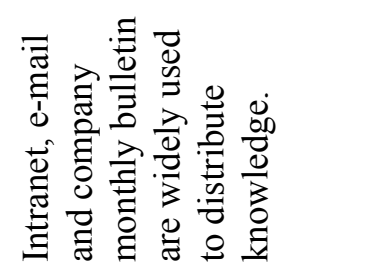 \\
\hline & 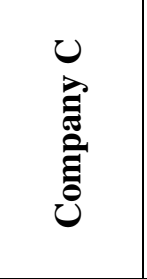 & 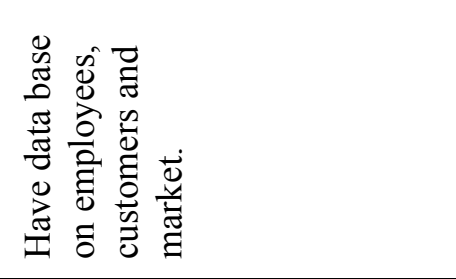 & 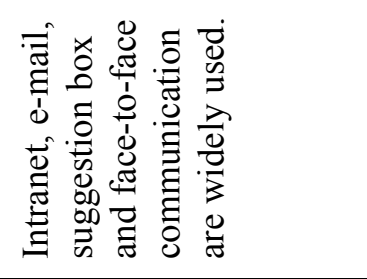 \\
\hline & 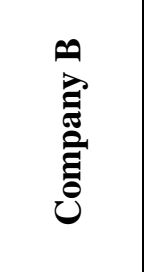 & 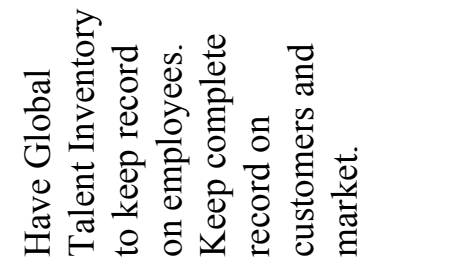 & 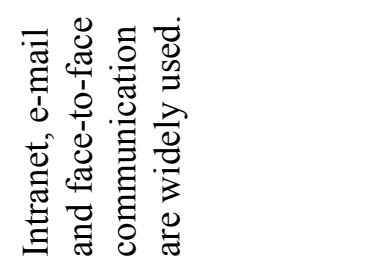 \\
\hline & 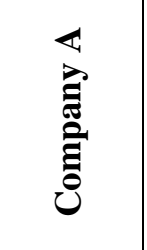 & 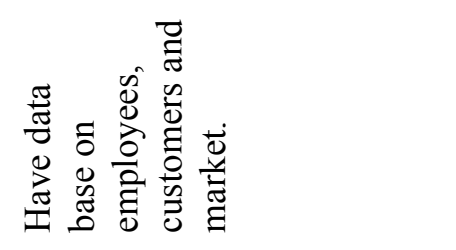 & 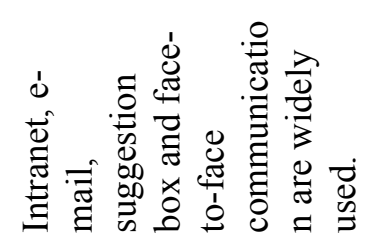 \\
\hline & 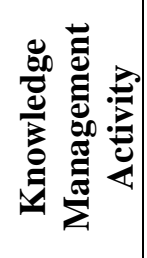 & 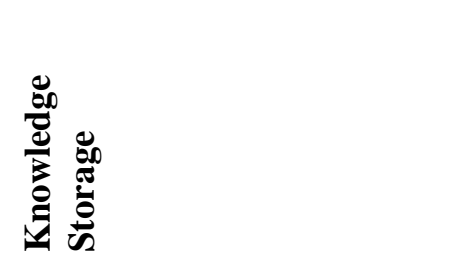 & 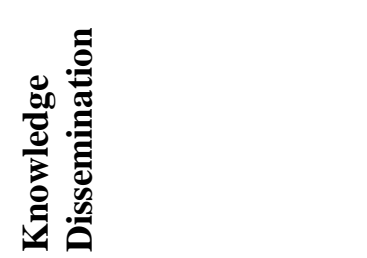 \\
\hline
\end{tabular}




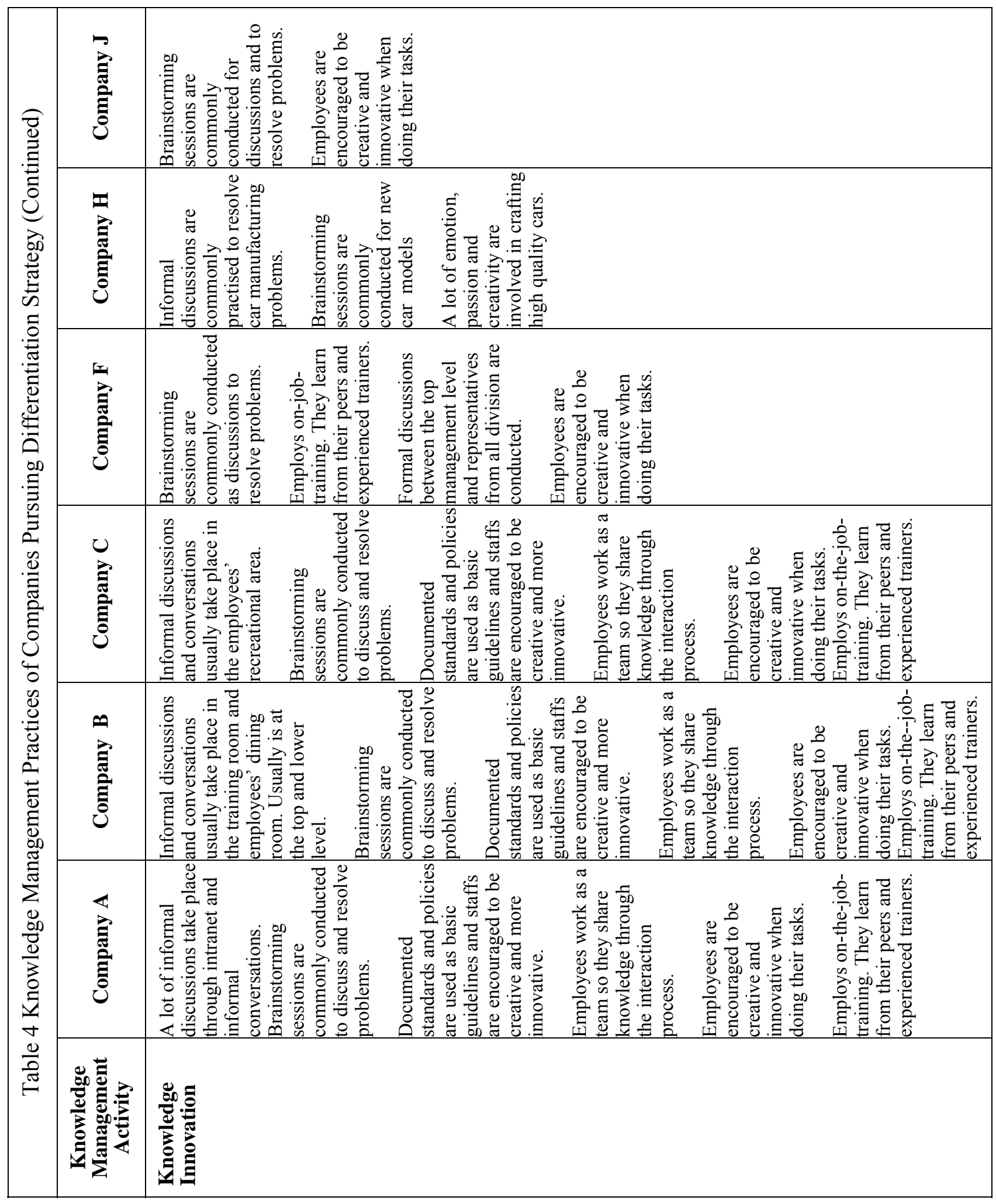




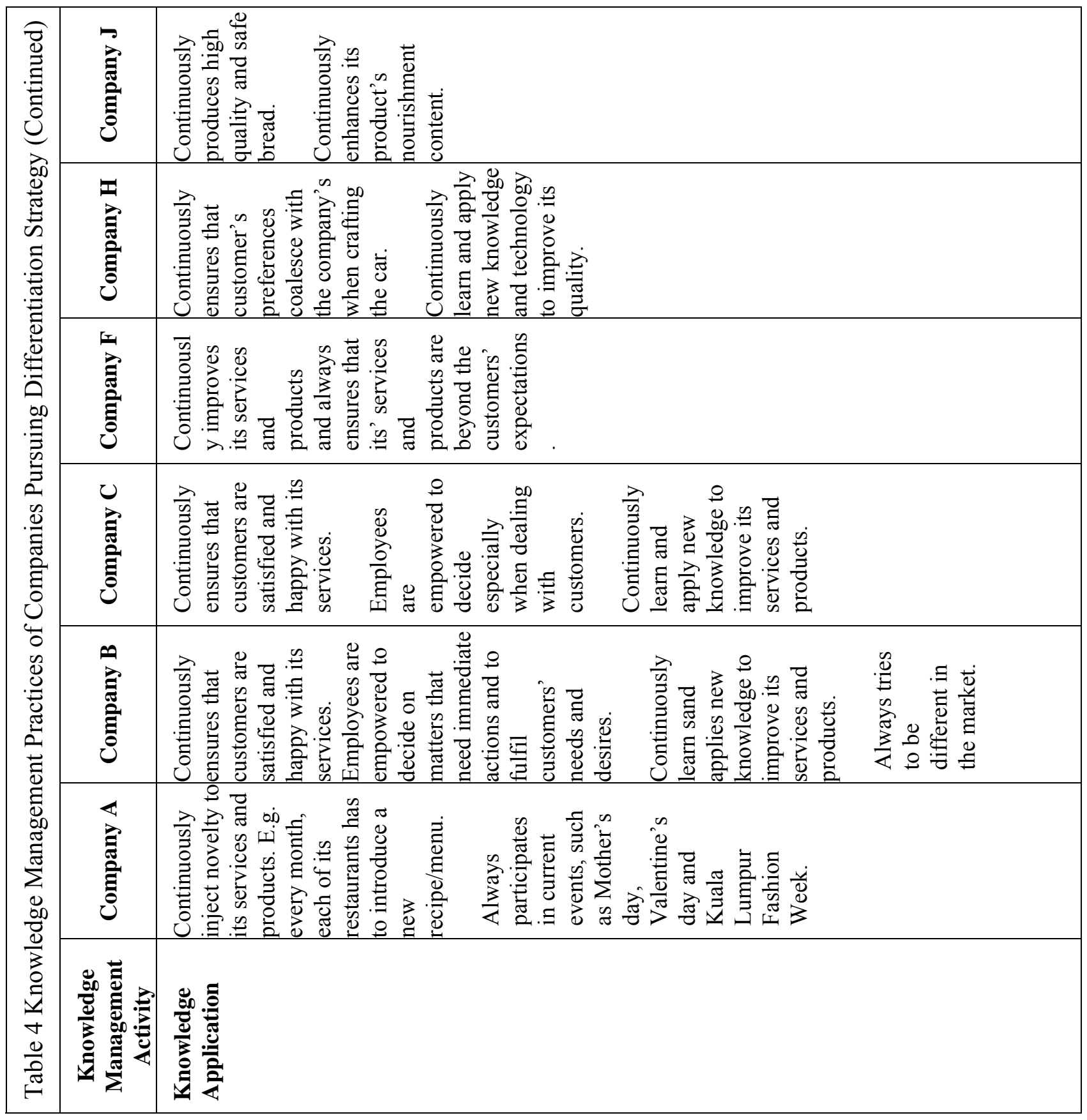


This study also found that companies pursuing differentiation strategy rely more on informal internal knowledge, that is, knowledge embedded in their employees. Employees are encouraged to be creative and innovative when doing their tasks and especially when matters are related to the customers. They rely heavily on their employees' innovativeness and creativity especially when it involves their customers. Employees are empowered and highly encouraged to use their own justifications and knowledge to fix problems that need immediate action and response. They are also involved in problem solving activities and they are encouraged to give ideas, suggestions and views so as to enhance the quality of products and services. This study also found that group discussions, e-mails and intranet are normally used to disseminate knowledge among the companies' members. Many 'live' interactions take place and informal discussions are commonly conducted to achieve solutions. Furthermore, they also practise working in teams and this helps to stimulate knowledge innovation through knowledge-sharing among employees.

Internalization is also highly practised in the differentiation strategy companies. Documented standards and procedures are used as basic guidelines and employees are empowered to apply their creativity and innovativeness in to enhance product and service quality. However, for Company $\mathrm{F}$ and $\mathrm{J}$, employees have to ensure that any action taken will not disrupt operational process. This study also found that the knowledge application activity in the differentiation strategy companies is focused on creating newness in the products and services provided. For example, the Human Resource Manager of Company $\mathrm{C}$ expressed, "Their opinions and views about works are always appreciated in developing newness in service".

Table 5 summarizes the knowledge management practices of the companies pursuing cost leadership strategy. For knowledge acquisition activity, these companies rely heavily on the companies' documented policies, procedures, guidelines and standards. Moreover, these documented materials are closely followed and the companies normally conduct regular inspections and monitor operations continuously to ensure that they are obeying standards and procedures. For companies such Companies D and E, they also obtain new knowledge from their franchisors. The franchisors monitor the management closely. For example, on regular basis, the franchisor will carry out inspections on Company D's operations. This is to ensure management efficiency and that all manuals provided are followed. The Financial Controller of Company D commented "inspection is mainly focused on operations". The study also reveals that cost 
leadership strategy companies also gain know-how skills either from their joint partner technology (Company I) or from vendors (Company I and K). Company I also receives feedbacks from branches and dealers about customers' expectations and the market.

As for knowledge dissemination activity, interactive approaches normally take place. Knowledge and information are disseminated through formal channels such as memos and meetings. Except for Company K, even though it practises face-to-face communications such meetings are mainly focused on explaining things more clearly. This is because most of its employees are foreigners and have language problems. The study also found that some companies use a lot of models or analogies to verbalise tacit knowledge into explicit knowledge. For example, flow charts and simple diagrams are commonly used in Company I to explain the production processes and tasks to be carried out in any workshop. Furthermore, some knowledge and information are restricted to a certain level and group of the companies' members. As Training Manager of Company I expressed, "Some knowledge cannot be disseminated to everybody. Some are confidential and are shared only among a certain level of people". In companies pursuing cost leadership strategy, meetings are commonly used towards delivering knowledge and information from the top management to its employees. Even though employees are given the opportunity to give their opinions and feedback, the final decision is made by the Managing Director. This study also found that the knowledge the companies obtained is more towards increasing the process efficiency and to reduce either the production costs or the operation costs. For example, in Company I, knowledge obtained from vendors is important to plan the amount of cars to produce and this could reduce the number of unsold cars, which indirectly will reduce production costs. Meanwhile for Company K, the knowledge that it gathers from its suppliers could reduce wastage level. 
Table 5 Knowledge Management Practices of the Companies Pursuing Cost Leadership Strategy

\begin{tabular}{|c|c|c|c|c|c|}
\hline $\begin{array}{c}\text { Knowledge } \\
\text { Management } \\
\text { Activities }\end{array}$ & Company D & Company E & Company G & Company I & Company $\mathrm{K}$ \\
\hline $\begin{array}{l}\text { Knowledge } \\
\text { Acquisition }\end{array}$ & $\begin{array}{l}\text { Standards, policies } \\
\text { and procedures are } \\
\text { closely referred to and } \\
\text { followed. } \\
\text { Output from } \\
\text { management meetings } \\
\text { are usually used for } \\
\text { making decisions and } \\
\text { resolving problems. } \\
\text { New knowledge is } \\
\text { also obtained from } \\
\text { franchisor. }\end{array}$ & $\begin{array}{l}\text { Standards, policies } \\
\text { and procedures are } \\
\text { closely referred to } \\
\text { and followed. } \\
\text { Output from } \\
\text { management } \\
\text { meetings are } \\
\text { usually used for } \\
\text { making decision } \\
\text { and resolving } \\
\text { problems. } \\
\text { New knowledge is } \\
\text { also obtained from } \\
\text { the Ministry of } \\
\text { Youth and Sports. }\end{array}$ & $\begin{array}{l}\text { Standards, policies } \\
\text { and procedures are } \\
\text { closely referred to } \\
\text { and followed. } \\
\text { Obtain new } \\
\text { technology } \\
\text { knowledge from } \\
\text { suppliers. } \\
\text { Up-date knowledge } \\
\text { from the regulatory } \\
\text { bodies. }\end{array}$ & $\begin{array}{l}\text { Gain new } \\
\text { knowledge } \\
\text { and skills from } \\
\text { the joint } \\
\text { technology } \\
\text { partner and } \\
\text { vendors. } \\
\text { Feedbacks } \\
\text { received from } \\
\text { branches are } \\
\text { used to predict } \\
\text { demand. } \\
\text { Standards, } \\
\text { policies and } \\
\text { procedures are } \\
\text { closely } \\
\text { referred to and } \\
\text { followed. }\end{array}$ & $\begin{array}{l}\text { Gains new } \\
\text { knowledge } \\
\text { from the } \\
\text { suppliers. } \\
\text { Standards, } \\
\text { policies and } \\
\text { procedures are } \\
\text { closely } \\
\text { referred to and } \\
\text { followed. }\end{array}$ \\
\hline $\begin{array}{l}\text { Knowledge } \\
\text { Storage }\end{array}$ & 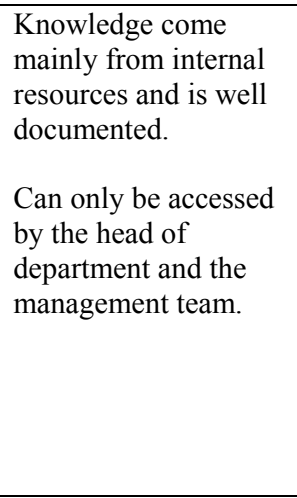 & $\begin{array}{l}\text { Knowledge is } \\
\text { mainly from } \\
\text { internal resources } \\
\text { and well } \\
\text { documented. } \\
\text { Can only be } \\
\text { accessed by the } \\
\text { heads of department } \\
\text { and the } \\
\text { management team. }\end{array}$ & $\begin{array}{l}\text { Knowledge is } \\
\text { mainly from } \\
\text { internal resources } \\
\text { and is well } \\
\text { documented. } \\
\text { Can only be } \\
\text { accessed by the } \\
\text { heads of department } \\
\text { and the } \\
\text { management team. }\end{array}$ & $\begin{array}{l}\text { Can only be } \\
\text { accessed by } \\
\text { the heads of } \\
\text { department } \\
\text { and the } \\
\text { management } \\
\text { team. }\end{array}$ & $\begin{array}{l}\text { Knowledge is } \\
\text { mainly from } \\
\text { internal } \\
\text { resources and } \\
\text { is well } \\
\text { documented. } \\
\text { Can only be } \\
\text { accessed by } \\
\text { the production } \\
\text { managers and } \\
\text { the } \\
\text { management } \\
\text { team. }\end{array}$ \\
\hline $\begin{array}{l}\text { Knowledge } \\
\text { Dissemination }\end{array}$ & $\begin{array}{l}\text { Usually through } \\
\text { memos and meetings. } \\
\text { Some knowledge and } \\
\text { information are } \\
\text { restricted only to a } \\
\text { certain group of } \\
\text { company's members. }\end{array}$ & $\begin{array}{l}\text { Formal interactive } \\
\text { approach such as } \\
\text { memos and } \\
\text { meetings. } \\
\text { Some knowledge } \\
\text { and information are } \\
\text { shared only among } \\
\text { a certain group of } \\
\text { company members. }\end{array}$ & $\begin{array}{l}\text { Knowledge is } \\
\text { disseminated } \\
\text { formally through } \\
\text { memos, e-mails and } \\
\text { meetings. } \\
\text { Some knowledge } \\
\text { and information are } \\
\text { shared only among } \\
\text { a certain group of } \\
\text { company members. }\end{array}$ & $\begin{array}{l}\text { Knowledge is } \\
\text { disseminated } \\
\text { formally } \\
\text { through } \\
\text { memos, e- } \\
\text { mails and } \\
\text { meetings. } \\
\text { Some } \\
\text { knowledge } \\
\text { and } \\
\text { information } \\
\text { are shared } \\
\text { only among a } \\
\text { certain group } \\
\text { of company } \\
\text { members. }\end{array}$ & $\begin{array}{l}\text { Formal face- } \\
\text { to-face } \\
\text { interactions }\end{array}$ \\
\hline
\end{tabular}


Table 5 Knowledge Management Practices of the Companies Pursuing Cost Leadership Strategy (Continued)

\begin{tabular}{|c|c|c|c|c|c|}
\hline $\begin{array}{c}\text { Knowledge } \\
\text { Management } \\
\text { Activities }\end{array}$ & Company D & Company E & Company G & Company I & Company $\mathrm{K}$ \\
\hline $\begin{array}{l}\text { Knowledge } \\
\text { Innovation }\end{array}$ & $\begin{array}{l}\text { Meetings are } \\
\text { commonly used to } \\
\text { explain and exchange } \\
\text { information within the } \\
\text { organization. } \\
\text { Existing manuals are } \\
\text { always referred to and } \\
\text { good value or newness } \\
\text { is added to increase } \\
\text { operational efficiency. } \\
\text { The actual outcomes } \\
\text { are always compared } \\
\text { and analyzed with the } \\
\text { predicted outcomes. }\end{array}$ & $\begin{array}{l}\text { Meetings are } \\
\text { commonly used to } \\
\text { explain and } \\
\text { exchange } \\
\text { information within } \\
\text { the organization } \\
\text { Existing manuals } \\
\text { are always referred } \\
\text { to and good value } \\
\text { or newness is added } \\
\text { to increase } \\
\text { operating } \\
\text { efficiency. } \\
\text { The actual } \\
\text { outcomes are } \\
\text { always compared } \\
\text { and analyzed with } \\
\text { the predicted } \\
\text { outcomes. }\end{array}$ & $\begin{array}{l}\text { Meetings are } \\
\text { commonly used to } \\
\text { explain and } \\
\text { exchange } \\
\text { information within } \\
\text { the organization } \\
\text { Existing manuals } \\
\text { are always referred } \\
\text { to and good values } \\
\text { or newness are } \\
\text { added to increase } \\
\text { the operating } \\
\text { efficiency. }\end{array}$ & $\begin{array}{l}\text { Meetings are } \\
\text { commonly } \\
\text { used to explain } \\
\text { and exchange } \\
\text { information } \\
\text { within the } \\
\text { organization } \\
\text { Existing } \\
\text { manuals are } \\
\text { always } \\
\text { referred to and } \\
\text { good values or } \\
\text { newness are } \\
\text { added to } \\
\text { increase the } \\
\text { operating } \\
\text { efficiency. } \\
\text { Knowledge } \\
\text { received from } \\
\text { the branches is } \\
\text { always } \\
\text { compared to } \\
\text { the company's } \\
\text { production and } \\
\text { marketing } \\
\text { plans. }\end{array}$ & $\begin{array}{l}\text { Knowledge } \\
\text { and } \\
\text { suggestions } \\
\text { received from } \\
\text { the suppliers } \\
\text { are always } \\
\text { added to the } \\
\text { company's } \\
\text { existing } \\
\text { procedures in } \\
\text { making bread. }\end{array}$ \\
\hline
\end{tabular}




\section{CONCLUSION}

The evidence reveals that the intellectual capital management practices by differentiation strategy companies emphasis more on the external knowledge, focus on developing individual knowledge, use interactive application repository of tacit knowledge, the knowledge innovation is through the process of socialization and internalization, and the knowledge application is to improve products and services quality. For cost leadership strategy, the knowledge management practices focus more on internal knowledge, emphasis on developing documenting organisational knowledge, use integrative application of explicit knowledge, the knowledge innovation is through the process of combination and externalization of explicit knowledge, and the knowledge application is to improve process efficiency and reduce costs.

\section{Summary of the Intellectual Capital Management Practice}

Table 6 Intellectual capital management practiced by organisation studied

\begin{tabular}{|l|l|l|}
\hline \multicolumn{1}{|c|}{$\begin{array}{c}\text { Knowledge } \\
\text { Managment Activities }\end{array}$} & Differentiation Strategy & Cost Leadership Strategy \\
\hline Knowledge Acquisition & $\begin{array}{l}\text { External resources } \\
\text { Internal informal resources }\end{array}$ & $\bullet$ Internal formal resources \\
\hline Knowledge Storage & $\bullet$ Individual knowledge & $\begin{array}{l}\text { Documented organisational } \\
\text { knowledge }\end{array}$ \\
\hline $\begin{array}{l}\text { Knowledge } \\
\text { Dissemination }\end{array}$ & $\bullet$ Interactive application & $\bullet$ Integrative application \\
\hline Knowledge Innovation & $\bullet \begin{array}{l}\text { Socialization and } \\
\text { internalization of tacit } \\
\text { knowledge }\end{array}$ & $\begin{array}{l}\text { Combination and } \\
\text { externalization of explicit } \\
\text { knowledge }\end{array}$ \\
\hline Knowledge Application & $\bullet \begin{array}{l}\text { Improving products and } \\
\text { services }\end{array}$ & $\begin{array}{l}\text { Improving process efficiency } \\
\text { and reducing costs }\end{array}$ \\
\hline
\end{tabular}

From the evidence obtained, this study proposes hypotheses which can be tested for future research:

The focus of intellectual capital management practices is related to the business strategy employed.

Ha1: The knowledge acquisition activity in organisations competing using cost leadership strategy will be more internally focused.

Hb1: The knowledge acquisition activity in organisations competing using differentiation 
strategy will be more externally focused.

Ha2: The knowledge storage activity in organisations competing using cost leadership strategy will put more emphasis on documenting organisational knowledge.

Hb2: The knowledge storage activity in organisations competing using differentiation strategy will put more emphasis on developing individual knowledge.

Ha3: The knowledge dissemination activity in organisations competing using cost leadership strategy will more likely employ integrative application repository of explicit knowledge.

Hb3: The knowledge dissemination activity in organisations competing using differentiation strategy will more likely employ interactive application repository of tacit knowledge.

Ha4: The knowledge innovation activity in organisations competing using cost leadership strategy will more likely take place through the process of combination and externalization of explicit knowledge.

Hb4: The knowledge innovation activity in organisations competing using differentiation strategy will more likely take place through the process of socialization and internalization of tacit knowledge.

Ha5: The knowledge application activity in organisations competing using cost leadership strategy will put more emphasis on improving process efficiency.

Hb5: The knowledge application activity in organisations competing using differentiation strategy will put more emphasis on improving products and services.

\section{REFERENCES}

Ambrosini, V., and Bowman, C. (2001). Tacit knowledge: some suggestions for opeartionalization. Journal of Management Studies, 38(6), 811-828.

Amit, R., and Schoemaker, P. J. H. (1993). Strategic assets and organizational ret. Strategic Management Journal, 14, 33-46.

April, K. A. (2002). Guidelines for developing a knowledge-strategy. Journal of Knowledge Management, 6(5), 445-456.

Barney, J. (1991). Firm resources and sustained competitive advantage. Journal of Management, 17(1), 99-120.

Benner, J. M., and Tushman, L. M. (2003). Exploitation, exploration and process management: the productivity dilemma revisited. Academy of Management Review, 28(2), $238-256$. 
Boudera, J. W., and Berger, C. J. (1985). Decision-theoric utility analysis applied to employee separations and acquisitional. Journal of Applied Psychology, 70, 581612.

Buller, P. F., and McEvoy (1991). Creating a sustaining ethical capability in the multinational corporation. Journal of World Business, Spring, 595-612.

Cappelli, P., and Crocker-Hefter, A. (1996). Distinctive human resources are firms core competencies. Organizational Dynamics, Winter, 7-22.

Chandler, A. (1962). Strategy and structure. Cambridge:.MIT Press.

Choi, B., and Lee, H. (2002). Knowledge management strategy and its link to knowledge creation process. Expert Systems with Application, 22(3), 173-187.

Demediuk, P. (2002). Intellectual capital Reporting: New Accounting for the New Economy. Asian Academy of Management Journal, 7(1), 57-74.

Dess, G.G., and Davis, P.S. (1984). Porter's 1980 generic strategy as determines of strategies group membership and organizational preference. Academy of Management Journal, 27(3), 121-143.

Du Plessis, M. (2005). Drivers of knowledge management in the corporate environment. International Journal of Information Market, 25(3), 193-205.

Edvinsson, L., and Malone, M. (1997). Intellectual capital: realising your company's true values by findings its hidden brainpowers. New York: Harper Business.

Finney, R. Z., Cambell, N. D., and Powell, C. M. (2004). Strategies and resources: pathways to success. Journal of Business Research, 11, 1-10.

Gopalakrishnan, S., Beirly, P., and Kessler, H. E. (1997). An examination of products and process innovation using a knowledge-based view. The Journal of High Technology Management Research, 10(1), 147-160.

Hall, P. and adrianni, P. (2002). Managing knowledge for innovation. Long Range Planning, 35, 29-48.

Harrison, S., \& Sullivan, H.P. (2002). Profiting from intellectual capital: learning from leading companies. Industrial and Commercial Training, 32(4), 139-148.

Hitt, M. A., Bierman, L., Shimizu, K., and Kochhar, R. (2001). Direct and moderating effects of human capital on strategy and performance in professional service firms: A Resource-based perspective. Academy of Management Journal, 44(1), 13-28.

Johannessen, J., Olsen, B., and Olsen, J. (2005). Intellectual capital as a holistic management philosophy: a theoretical perspective. International Journal of Information Management, 25, 151-171. 
Kamoche, K. (1996). Strategv HRM within a resource-capability view of the firm. Journal of Management Studies, 33(2), 213-223.

Lee, C. C., and Yang, J. (2000). Knowledge value chain. Journal of Management Development, 19(9), 783-793.

Lepak, D. P., and Snell, S. A. (1999). The human resource architecture: Towards a theory of human capital allocation and development. Academy of Management Review, 24, 31-48.

Lim, K. K. (1999). Managing for quality through knowledge management. Total Quality Management, 10, 615-621.

Miller, D. (1986). Configuration of strategy and structure: Towards a synthesis. Strategic Management Journal, 7, 233-249.

Miller, D., and Shamsie, J. (1996). The resources-based view of the firm in two environments; The Hollywood firm studios from 1936 to 1965. Academy of Management Journal, 39, 340-367.

Mouritsen, J., Bukh, P. N., Larsen, H. T., and Johansen, M. R. (2002). Developing and managing knowledge through intellectual capital statements. Journal of Intellectual Capital, 3(1), 10-29.

Mouritsen, J., and Larsen, H. T. (2001). Intellectual capital and the "capable firm", narrating, visualizing and numbering for managing knowledge. Accounting, Organizations and Society, 26, 735-762.

Ndlela, L. T., and du Toit, A. S. A. (2001). Establishing a knowledge management preference for competitive advantage in an enterprise. International Journal of Innovation Management, 21(2), 151-165.

O’Donnell, F., O’Regan, P., Coates, B., Kenedy, T., Keary, B., and Bekery, G. (2003). Human interaction: the critical sources of intangible value. Journal of Intellectual Capital, 4(1), 82-99.

Pehrson, A. (2001). The strategic states model: optimum strategies to reach high performance. Management Decision, 39(6), 441-447.

Pena, I. (2002). Intellectual capital and business start-up success. Journal of Intellectual Capital, 3(2), 180-198.

Penninggs, J. M., Lee, K., and van Witteloostuijn, A. (1998). Human capital, social capital and firm dissolution. Academy of Management Journal, 41, 425-440.

Peppard, J., and Rylander, A. (2001). Using intellectual capital perspective to design and implement a growth strategy. European Management Journal, Oct, 510-525. 
Peteraf, G. (1994). The cornerstone of competitive advantage: A resourced based view. Strategic Management Journal, 14, 179-191.

Pitts R., and Lei, D. (2003). Strategic management: Building and sustaining competitive advantage. South-Western: Thompson.

Porter, M. E. (1980). Competitive Strategy. New York: Free Press.

Roos, J., and Victor, B. (1999). Towards new model of strategy-making as serious play. European Management Journal, 17(4), 348-358.

Russell, C. J., Colella, A., and Bobko, P. (1991). Expanding the context of utility: the strategic impact of personnel selection. Personnel Psychology, 46, 781-801.

Schuler, R. S. (1989). Strategic human resource management and industrial relations. Human Resources, 42(2), 157-184.

Stewart, T. (2002). The wealth of knowledge: Intellectual capital and twenty-first century organization. London: Nicholas Brealey Publishing Limited.

Stewart, T. (1997). Tom Stewart on Intellectual Capital.Retrieved. July, 2003, from http://www.brint.com.

Sullivan, P. H. (1999). Profitability for intellectual capital. Journal of Knowledge Management, 3(2), 132-143.

Sveiby, K. E. (1997). The intangible asset monitor. Journal of Human Resource Costing and Accounting, 2(1), 73-97.

Ulrish, W. (1998). System thinking, system practice, and practical philosophy: a program for research. System Practice, 1, 137-163.

Volpel, S. (2000). Strategic intellectual capital. Journal of Intellectual Capital, 3(2), 118127.

Wiig, K. M. (1999a). The intelligent enterprise and knowledge management. Article prepared for UNESCO's encyclopedia of life support systems. Knowledge Rersearch Institute.

Wiig, K. M. (1999b). Comprehensive knowledge management. Working paper.

Knowledge Rersearch Institute, \#1999-4, Revision 2. 